\title{
Reply to the Letter to the editor in response to the Position statement and best practice recommendations on the imaging use of ultrasound from the European Society of Radiology ultrasound subcommittee
}

\author{
Adrian P. Brady ${ }^{1,2^{*}}$, Dirk-André Clevert ${ }^{3}$, Paul S. Sidhu ${ }^{4}$ and on behalf of the European Society of Radiology \\ ultrasound subcommittee ${ }^{5}$
}

Dear Editor in Chief,

We welcome the letter's authors' interest in our paper "Position statement and best practice recommendations on the imaging use of ultrasound from the European Society of Radiology ultrasound subcommittee", published in Insights into Imaging in November 2020 [1].

The Ultrasound subcommittee of the European Society of Radiology endeavours to focus in its publications on matters of broad interest across our member countries [2-5]. Our principal goal is to promote appropriate use of ultrasound as an imaging modality, and to define standards for such use, in the best interests of patients. Matters of licensing, registration, qualifications and regulation of who performs ultrasound imaging are specific to each country, and vary widely across Europe. Such matters, while of importance within each individual country, are beyond the scope of ESR publications on standards.

We re-affirm that ultrasound should be performed by fully-trained, competent individuals, who adhere to formal standards of required training, education and practice (as outlined in our position paper), and who abide by their relevant country's regulatory regime.

Yours sincerely.
Authors' contributions

All authors read and approved the final manuscript.

Funding

The authors declare that this article has not received funding.

Availability of data and materials

Not applicable.

\section{Declarations}

Ethics approval and consent to participate

Not applicable.

Consent for publication

Not applicable.

Competing interests

The authors declare that they have no competing interest.

Author details

${ }^{1}$ Radiology Department, Mercy University Hospital, Grenville Place, CorkT12 WE28, Ireland. ${ }^{2}$ University College Cork, Cork, Ireland. ${ }^{3}$ Department of Clinical Radiology, Interdisciplinary Ultrasound-Center, Munich University Hospital, Munich, Germany. ${ }^{4}$ Department of Radiology, King's College Hospital, London, UK. ${ }^{5}$ Am Gestade 1, 1010 Vienna, Austria.

Received: 16 April 2021 Accepted: 27 April 2021

Published online: 21 May 2021

\footnotetext{
*Correspondence: adrianbrady@me.com

${ }^{1}$ Radiology Department, Mercy University Hospital, Grenville Place,

Cork T12 WE28, Ireland

Full list of author information is available at the end of the article
} 


\section{Reference}

1. European Society of Radiology (ESR) (2020) Position statement and best practice recommendations on the imaging use of ultrasound from the European Society of Radiology ultrasound subcommittee. Insights Imaging 11(1):115

2. ESR statement on portable ultrasound devices (2019) European Society of Radiology (ESR). Insights Imaging 10(1):89

3. European Society of Radiology (ESR) (2019) Abdominal applications of ultrasound fusion imaging technique: liver, kidney, and pancreas. Insights Imaging 10(1):6

4. Nyhsen CM, Humphreys H, Koerner RJ et al (2017) Infection prevention and control in ultrasound - best practice recommendations from the
European Society of Radiology Ultrasound Working Group. Insights Imaging 8(6):523-535

5. Mostbeck G, Adam J, Michael Bachmann Nielsen M et al (2016) How to diagnose acute appendicitis: ultrasound first. Insights Imaging $7(2): 255-263$

\section{Publisher's Note}

Springer Nature remains neutral with regard to jurisdictional claims in published maps and institutional affiliations.

\section{Submit your manuscript to a SpringerOpen ${ }^{\circ}$ journal and benefit from:}

- Convenient online submission

- Rigorous peer review

- Open access: articles freely available online

- High visibility within the field

- Retaining the copyright to your article

Submit your next manuscript at $\boldsymbol{\nabla}$ springeropen.com 